\title{
In Situ IgM Production and Clonal Expansion of B-1 Cells in Peritoneal Cavity Promote Elimination of C. albicans Infection in IgH Transgenic Mice with $\mathrm{V}_{\mathrm{H}}$ Derived from a Natural Antibody
}

\author{
Rong Tian ${ }^{1,29}$, Meng $\mathrm{Fu}^{29}$, Zhuo Zhang ${ }^{39}$, Jing Ren², Jingang An², Yufeng Liu², Wei Li ${ }^{1,2 *}$ \\ 1 Department of Dermatology, General Hospital of the Air Force, Beijing, P. R. China, 2 Department of Dermatology, Xijing Hospital, Xi'an, P. R. China, 3 Department of
} Neurology, Tangdu Hospital, Xi'an, P. R. China

\begin{abstract}
B-1 cells are innate-like cells that play important roles in host defense against infection. However, the function of B-1 cells in fungi infection remains unclear. Previously we produced $\lg \mathrm{H}$ transgenic mice $\mathrm{TgV}_{\mathrm{H}} 3 \mathrm{~B} 4$ with $\mathrm{V}_{\mathrm{H}}$ derived from a natural antibody 3B4 that can identify $C$. albicans, and found that $\operatorname{TgV}_{\mathrm{H}} 3 \mathrm{~B} 4$ mice were resistant to intraperitoneal (i. p.) and intravenous $C$. albicans infection. Most of the peritoneal cavity (PEC) B-1 cells in $\mathrm{TgV}_{\mathrm{H}} 3 \mathrm{~B} 4$ mice express transgenic BCR that binds $C$. albicans. In the present study, we explored the response of B-1 cells to $C$. albicans infection by applying $i . p$. inoculation of fungi in $\mathrm{TgV}_{\mathrm{H}} 3 \mathrm{~B} 4$ mice. We found that $C$. albicans was cleared more efficiently in $\mathrm{TgV}_{\mathrm{H}} 3 \mathrm{~B} 4$ mice after i. $p$. inoculation than that of littermate control. The level of $C$. albicans-reactive IgM in $\mathrm{PEC}$ of $\mathrm{TgV}_{\mathrm{H}} 3 \mathrm{~B} 4$ mice was much higher than that of control, and the number of $\mathrm{B}-1 \mathrm{a} B$ cells was also elevated in $\mathrm{TgV}_{\mathrm{H}} 3 \mathrm{~B} 4$ mice, which was mainly due to enhanced proliferation of B-1 cells. Additionally, numbers of $C$. albicans-specific B cells increased greatly in $\mathrm{TgV}_{\mathrm{H}} 3 \mathrm{~B} 4$ mice after $C$. albicans inoculation. Our data suggested that in situ IgM production and clonal expansion of B-1 cells in PEC participate in host defense against C. albicans infection.
\end{abstract}

Citation: Tian R, Fu M, Zhang Z, Ren J, An J, et al. (2013) In Situ IgM Production and Clonal Expansion of B-1 Cells in Peritoneal Cavity Promote Elimination of C. albicans Infection in IgH Transgenic Mice with $\mathrm{V}_{\mathrm{H}}$ Derived from a Natural Antibody. PLoS ONE 8(4): e60779. doi:10.1371/journal.pone.0060779

Editor: Jianqing $\mathrm{Xu}$, Fudan University, China

Received September 20, 2012; Accepted March 2, 2013; Published April 2, 2013

Copyright: (C) 2013 Tian et al. This is an open-access article distributed under the terms of the Creative Commons Attribution License, which permits unrestricted use, distribution, and reproduction in any medium, provided the original author and source are credited.

Funding: This work was supported by grants from the National Natural Science Foundation of China (30771949 and 31070793 for W. Li; 30872299 and 30972641 for Y.F. Liu). The funders had no role in study design, data collection and analysis, decision to publish, or preparation of the manuscript.

Competing Interests: The authors have declared that no competing interests exist.

*E-mail: liwei1@fmmu.edu.cn

9 These authors contributed equally to this work.

\section{Introduction}

Natural antibodies, major component of the innate humoral immunity [1,2], have been shown to be important in innate and adaptive immune responses against microbial infections [3-7]. The poly-reactive natural IgM and surface antigen receptor expressed by B-1 cells might be a kind of pattern recognition receptors [8], and can recognize invariant molecular structures shared by large groups of pathogens, including many fungi [8-10]. The protective role of natural antibodies against bacteria and virus infection has long been recognized [4,6], however, the importance of natural antibodies in host defense against fungi infection has not been revealed untill recently. B cell-depleted mice have been shown to be more susceptible to systemic candidiasis than controls [11], and B cell knockout mice are easier to develop systemic, but not mucosal, candidiasis [12]. More recently, Kozel's group showed that a mannan-specific IgG antibody from normal human mediates C3-binding and killing of C. albicans [13,14]. We produced a monoclonal polyreactive natural antibody $[8,15]$, 3B4, which not only recognizes self-antigen keratin, but also recognizes a surface antigen located in the germ tubes of $C$. albicans, and protects mice from C. albicans-induced death with passive immunization, by mechanisms involving suppression of germ tube formation and modulation of phagocytosis [8]. Using the $\mathrm{V}_{\mathrm{H}}$ gene from $3 \mathrm{~B} 4$, we constructed a $\mu$ chain transgenic mouse $\left(\mathrm{TgV}_{\mathrm{H}} 3 \mathrm{~B} 4\right)$ which has elevated serum anti-C. albicans $\operatorname{IgM}$ and is resistant to $C$. albicans infections. Analyses of $\mathrm{B}$ cell development showed that in $\mathrm{TgV}_{\mathrm{H}} 3 \mathrm{~B} 4$, most $\mathrm{B}$ cells secreting C. albicans-reactive antibodies are selected into the B-1 B cell compartment [8]. These results demonstrate a key role of natural antibodies in anti- $C$. albicans immune responses, and also indicate that B-1 cells may be important in anti-fungi immunity.

B-1 cells are distinguished from other subsets of B cells by their anatomical localization, phenotype, self-renewing capacity, and production of natural antibodies [16,17]. B-1 cells constitute a major fraction of $\mathrm{B}$ cells present in peritoneal cavity (PEG), and are a minor fraction of $B$ cells in spleen $[16,17]$. Based on cell surface CD5 expression, B- 1 cells are subdivided into the $\mathrm{B}-1 \mathrm{a}\left(\mathrm{CD} 5^{+}\right)$and B-1b (CD5 ${ }^{-}$) subsets, and B-1 cells in PEC also express Mac-1. Although the origin of $\mathrm{B}-1$ cells is still in debate, there is evidence indicating that B-1 cells are positively selected by self-antigens, and strong BCR antigen signals appear to be important for the decision to become B-1 cells $[16,18,19]$. B-1 cells are characterized by the production of natural antibodies in the absence of apparent infection or immunization [16], and B-1-specific antibodies are involved in many biological events, such as reducing atheroscle- 
rotic lesions, activating $\mathrm{T}$ cell responses, contributing to autoimmunity, and promoting ischemia/reperfusion injury [20-22]. Most importantly, B-1 cells are envisioned as key players in the early humoral response against pathogens and are thought to be the primary antibody producers in response to $\mathrm{T}$ cell-independent type 2 (TI-2) antigens along with marginal zone B cells [23-25]. However, the role of B-1 cells in fungal infection and how B-1 cells respond to pathogen infection in peritoneal cavity are still not clear.

In the present study, intraperitoneal (i. p.) C. albicans inoculation was applied to our transgenic model of $\mathrm{TgV}_{\mathrm{H}} 3 \mathrm{~B} 4$, in which $C$. albicans-reactive $\mathrm{B}-1$ cells were enriched in $\mathrm{PEC}$, to explore the role and immune response of B-1 cells in fungi infection. Our data showed that C. albicans-specific B-1 cells proliferated actively and produced a large amount of natural IgM to clear the pathogen, indicating that B-1 cells play a critical role in host defense against C. albicans infection.

\section{Results}

\section{Efficient clearance of $C$. albicans in PEC of TgVH3B4}

In previous study, we found $\mathrm{TgV}_{\mathrm{H}} 3 \mathrm{~B} 4$ mice were resistant to both intravenous (i. v.) and i. p. C. albicans infection. In particular, almost complete protection was observed in i. p. inoculation with a relatively high number of fungi in $\mathrm{TgV}_{\mathrm{H}} 3 \mathrm{~B} 4$ mice [8]. It seemed likely that local environment of PEC might exert more efficient defense against $C$. albicans infection. In this study, we set out to analyze in detail the antibody and B-1 cell responses in PEC after i. p. C. albicans inoculation. A lower dose of C. albicans $\left(2 \times 10^{6}\right)$ was applied for i. p. inoculation, and our previous study has shown that the infection would be restricted in PEC and all the mice would survive.

The C. albicans burden and inflammatory infiltration in PEC after fungi inoculation were analyzed in $\mathrm{TgV}_{\mathrm{H}} 3 \mathrm{~B} 4$ mice and littermate control. At different time point after C. albicans inoculation, the lavages were eluted from the mice. The supernatant of the elution was subjected to inflammatory cytokine analysis, and the cells in the elution were subjected for colonyforming assay and FCM analysis. The colony-forming units (CFU) of the elution after C. albicans inoculation decreased with time, and level of inflammatory cytokines and neutrophil infiltration increased gradually and began to decrease from $36 \mathrm{~h}$ after inoculation. The data at $36 \mathrm{~h}$ after inoculation were shown in Fig. 1. The number of living yeasts in the lavage of $\mathrm{TgV}_{\mathrm{H}} 3 \mathrm{~B} 4$ mice was much lower than that of control (Fig. 1A). The concentrations of inflammatory cytokines, TNF-a, IL-6 and MCP-1, were approximately 3 folds lower in $\mathrm{TgV}_{\mathrm{H}} 3 \mathrm{~B} 4$ mice than that of their littermates (Fig. 1B). There were fewer neutrophils in the PEC lavage of $\mathrm{TgV}_{\mathrm{H}} 3 \mathrm{~B} 4$ mice when analyzed using anti-Grl antibody (Fig. 1G). These data showed that there were less C. albicans burden, less neutrophil infiltration and inflammatory cytokines in PEC of $\mathrm{TgV}_{\mathrm{H}} 3 \mathrm{~B} 4$ mice, indicating that $C$. albicans was cleared more efficiently in $\mathrm{TgV}_{\mathrm{H}} 3 \mathrm{~B} 4$ mice.

\section{Elevated IgM production in PEC of TgVH3B4}

B-1 cells are the major source of natural IgM antibodies which constitute the first line of defense against infection. In the $\mathrm{TgV}_{\mathrm{H}} 3 \mathrm{~B} 4$ mice, most $\mathrm{B}$ cells in PEC produce the $3 \mathrm{~B} 4 \mathrm{IgM}$ that can recognize $C$. albicans $[8,26]$. Our previous study have demonstrated that the $3 \mathrm{~B} 4$ antibody protected mice from $C$. albicans-induced death in passive immunization, by mechanisms involving suppressing the germ tube formation and modulating phagocytosis. Thus, to elucidate the mechanism for the enhanced clearance of $C$. albicans in $\mathrm{TgV}_{\mathrm{H}} 3 \mathrm{~B} 4$ mice, we first analyzed the antibodies production in PEC before and after fungi inoculation.

Before fungi inoculation the total IgM level was almost the same between $\mathrm{TgV}_{\mathrm{H}} 3 \mathrm{~B} 4$ mice and control, however, the level of $C$. albicans-specific IgM in PEC of $\mathrm{TgV}_{\mathrm{H}} 3 \mathrm{~B} 4$ mice was much higher than that of control (Fig. 2A-B). After C. albicans inoculation, the total IgM level increased slightly in both $\mathrm{TgV}_{\mathrm{H}} 3 \mathrm{~B} 4$ and control mice, as shown in Fig. 2A. However, the level of $C$. albicans-specific IgM increased greatly in $\mathrm{TgV}_{\mathrm{H}} 3 \mathrm{~B} 4$ mice, in contrast to a slight increase of anti-C. albicans IgM in the control mice (Fig. 2B). There was no difference of total and C. albicans-specific IgG antibodies in PEC elution before and after inoculation between $\mathrm{TgV}_{\mathrm{H}} 3 \mathrm{~B} 4$ mice and control (data not shown). These data indicated that B-1 cells produce natural IgM in PEC at a baseline level in normal conditions, and are stimulated to produce larger amount of antigen-specific antibodies upon pathogen inoculation.

\section{Increased proliferation of B-1 cells after C. albicans inoculation}

As B-1 cells are the major producing cells of natural antibodies, we analyzed B-1 cells' number and proliferation in PEC after $C$. albicans infection. Dynamic analysis of $\mathrm{B}$ cell numbers showed that there was a transient decrease of B-1 cell numbers in PEC after $C$. albicans inoculation, and then the numbers increased and peaked at $36 \mathrm{~h}$ after inoculation (data not shown). The subsets of B-1 cells were analyzed at $36 \mathrm{~h}$ after inoculation as shown in Fig. 3. The number of $\mathrm{CD}^{+} \mathrm{B}-1 \mathrm{a}$ cells in $\mathrm{TgV}_{\mathrm{H}} 3 \mathrm{~B} 4$ was higher than that of littermate before C. albicans inoculation (Fig. 3), which has been reported in our previous study [8]. While after C. albicans inoculation, numbers of $\mathrm{B}-\mathrm{la}$ cells increased in both $\mathrm{TgV}_{\mathrm{H}} 3 \mathrm{~B} 4$ and littermate, and $\mathrm{TgV}_{\mathrm{H}} 3 \mathrm{~B} 4$ has higher number of $\mathrm{B}-\mathrm{la}$ cells.

The increase in B-la cell number may be the result of enhanced proliferation or accelerated migration. Consequently, we further assessed the proliferation of B-1 cells by using BrdU incorporation assay. Results showed that before PEC inoculation there was only a detectable incorporation of BrdU in B-la and $\mathrm{B}-1 \mathrm{~b}$ cells in both $\mathrm{TgV}_{\mathrm{H}} 3 \mathrm{~B} 4$ and control mice (data not shown). After PEC $C$. albicans inoculation, there were marked proliferation of both B-la and B-lb cells, as shown by $19 \%$ and $10 \%$ BrdU $^{+}$cells (Fig. 4). The proliferation of $\mathrm{B}-1$ a cells in $\mathrm{TgV}_{\mathrm{H}} 3 \mathrm{~B} 4$ was greater than that of B-1b cells, indicating that B-la cells responded more actively in immediate immunity to C. albicans infection.

\section{Clonal expansion of C. albicans-specific B cells in TgVH3B4}

To determine the antigen-specificity of the proliferating B cells after C. albicans inoculation in PEC, we sorted B cells by magnetic beads from PEC, and analyzed by using ELISPOT assay with keratin as coating antigen [8], as polyreactive natural antibody 3B4 can identify both C. albicans and keratin. Before C. albicans inoculation, there were more keratin reactive $\mathrm{B}$ cells in PEC of $\mathrm{TgV}_{\mathrm{H}} 3 \mathrm{~B} 4$ mice than control, which has been shown in previous study $[8,26]$. After i. p. C. albicans inoculation, there were even more $\mathrm{B}$ cells secreting keratin-reactive $\mathrm{IgM}$ in $\mathrm{TgV}_{\mathrm{H}} 3 \mathrm{~B} 4$ mice (Fig. 5A). In the PEC of littermate control, there were also more keratin-reactive $\mathrm{B}$ cells after fungal inoculation, but the increasing scope was very limited (Fig. 5A). When B cells from PEC were cocultured with irradiated C. albicans, both total IgM and C. albicansspecific IgM in the supernatant were much higher in $\mathrm{TgV}_{\mathrm{H}} 3 \mathrm{~B} 4$ mice than that of control (Fig. 5B). These data indicated that there was active clonal expansion of $C$. albicans-specific B-1 cells in $\mathrm{TgV}_{\mathrm{H}} 3 \mathrm{~B} 4$ mice after infection with C. albicans. 
A

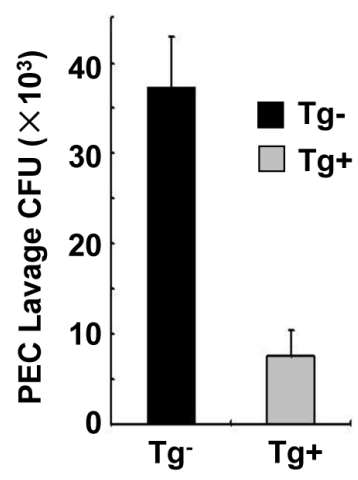

B

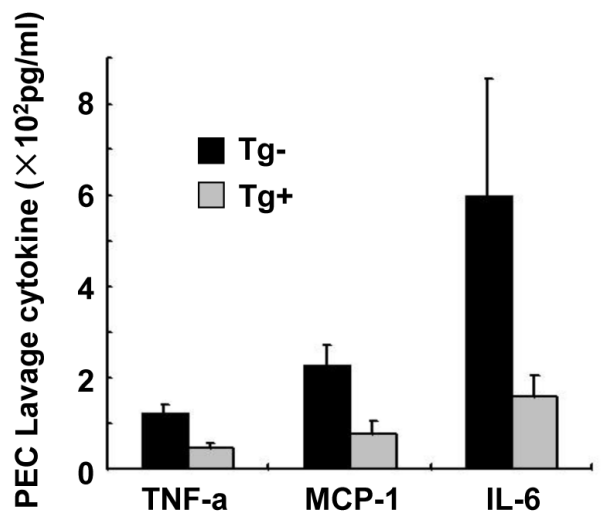

C
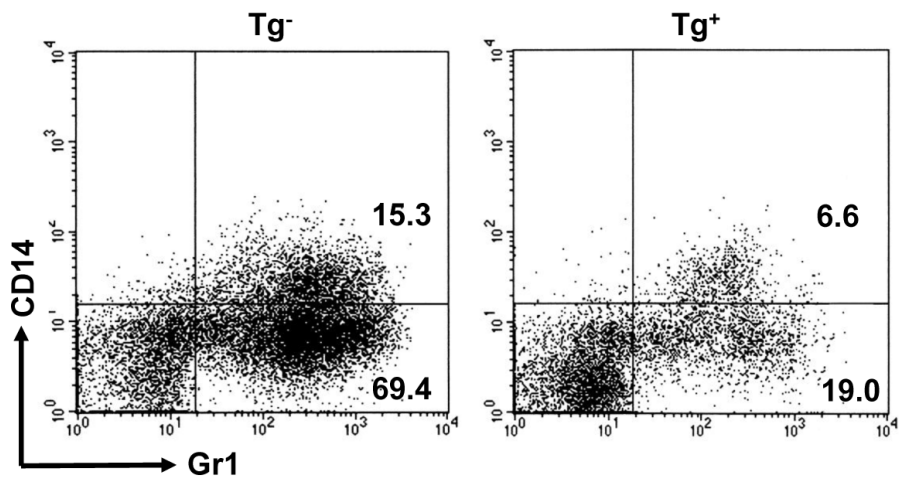

Figure 1. C. albicans burden and inflammatory infiltration after i. p. inoculation. $2 \times 10^{6}$ C. albicans yeasts were i. p. injected into $\mathrm{TgV}_{\mathrm{H}} 3 \mathrm{~B} 4$ mice and littermate. At different time point the mice were sacrificed and PEC lavage was eluted by PBS. Results obtained from elution at $36 \mathrm{~h}$ after the inoculation were shown. Living yeasts in the elution were assessed by a colony-forming assay (A), and supernatant of the elution was subjected to inflammation cytokines analysis by a Cytometry Beads Array kit (B). Data shown are means $\pm S D, n=6 . * P<0.01$. (C) Cells collected from the PEC elution were stained with antibodies and analyzed by FCM. Data are representative of four independent experiments.

doi:10.1371/journal.pone.0060779.g001

\section{Discussion}

B-1 cells reside predominantly in the PEC, bearing several features of activated B cells, and act as key players in the early humoral response against pathogens by producing natural antibodies [16]. From an evolutionary point of view, it is interesting to note that B-1 cells may represent a transitional phase on the evolution of the adaptive immune response, guarding the main compartments of the primitive organism, the body cavity [27]. One function of peritoneal $\mathrm{Bl}$ cells is to survey the abdominal cavity and to join forces with innate cells, such as
A

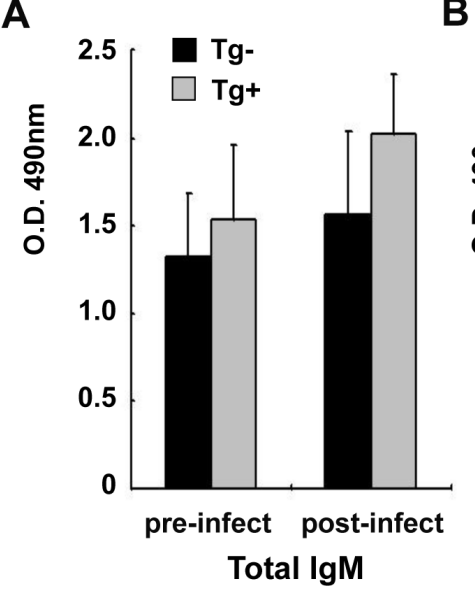

B

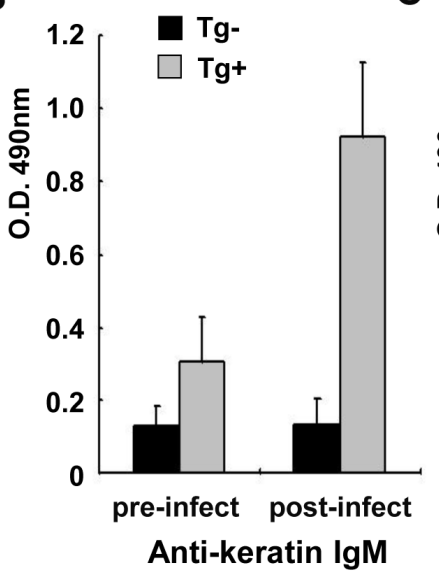

C

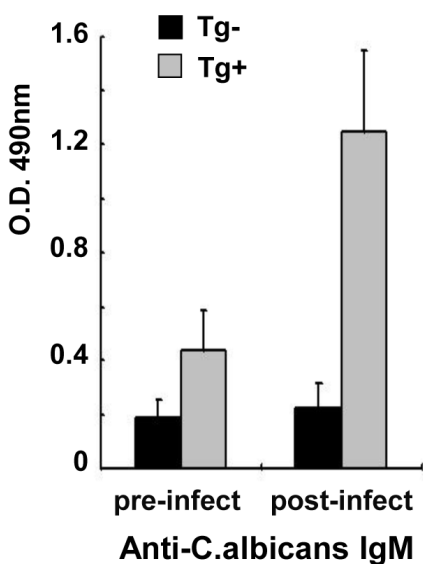

Figure 2. Natural IgM production in PEC. PEC lavage before and after $C$. albicans inoculation were detected by ELISA using plate coated with anti-mouse IgM antibody or live C. albicans. (A) Total IgM, (B) C.albicans-specific IgM. Data shown are means $\pm S D, n=6 .{ }^{*} P<0.01$. doi:10.1371/journal.pone.0060779.g002 

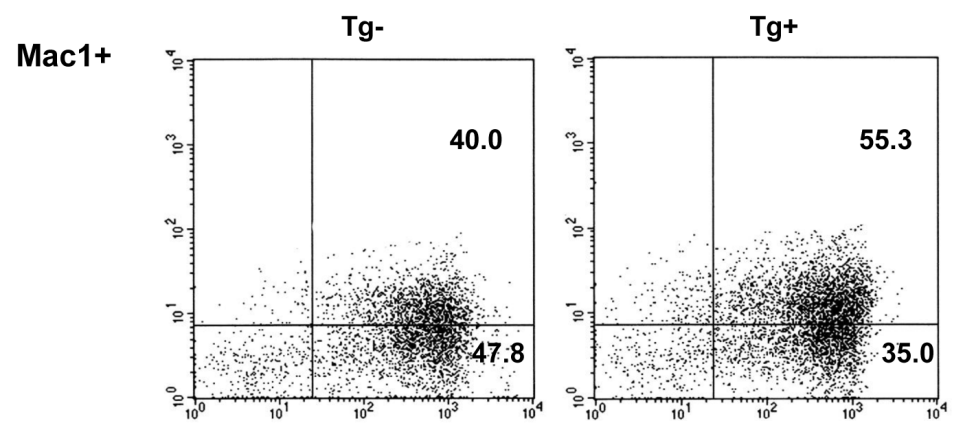

\section{Pre-infect}
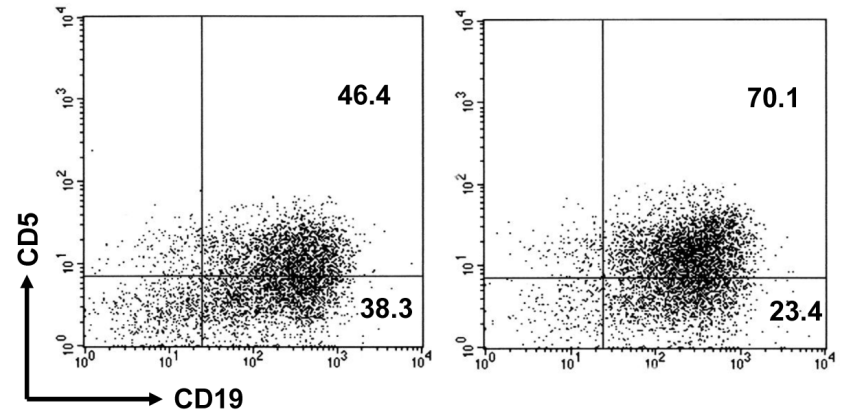

Post-infect

Figure 3. B cell analysis in PEC. Cells collected the PEC lavage before and after C.albicans inoculation were stained with antibodies and analyzed by FCM. Data are representative of four independent experiments.

doi:10.1371/journal.pone.0060779.g003

Tg-
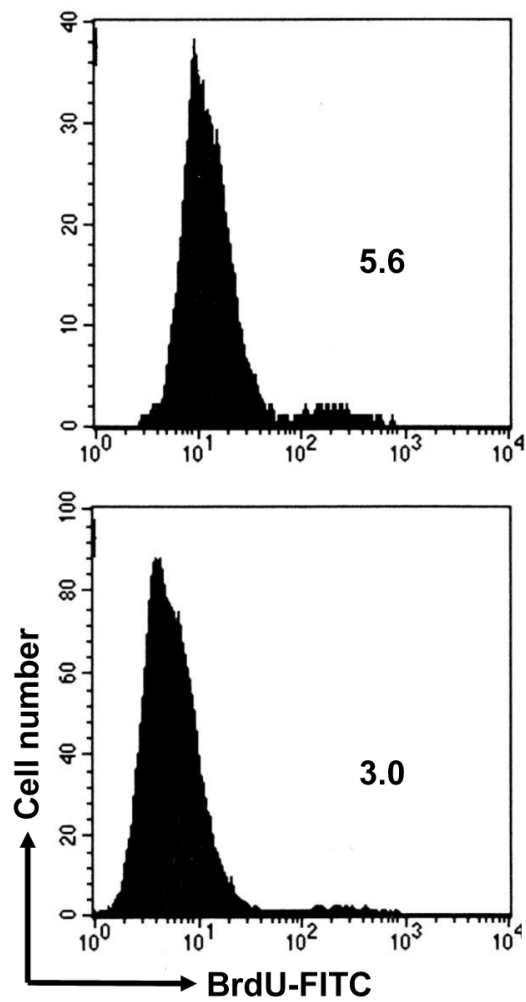

$\mathrm{Tg}+$
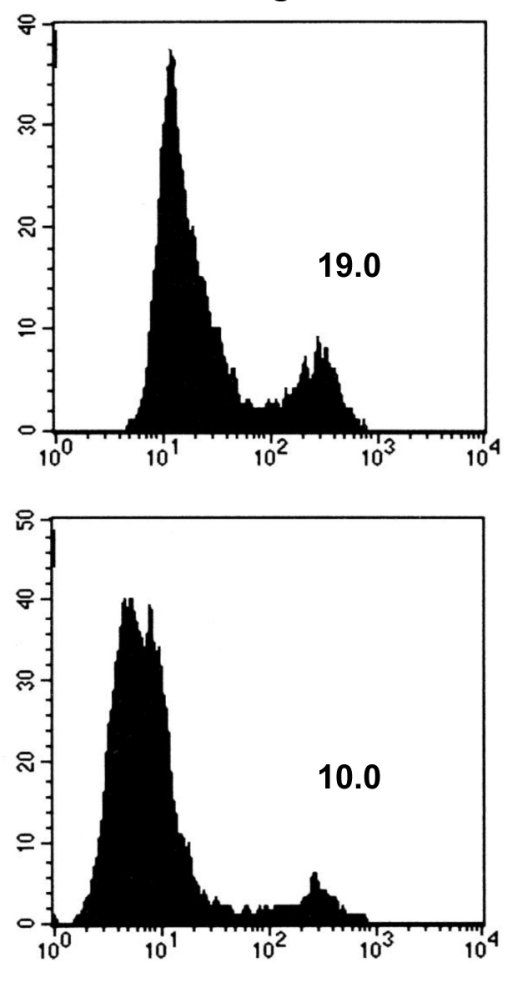

\section{CD19+CD5+}

\section{CD19+CD5-}

Figure 4. BrdU incorporation assay. BrdU was i. p. injected with $C$. albicans inoculation to $\mathrm{TgV}_{\mathrm{H}} 3 \mathrm{~B} 4$ mice and littermate, and injected for the second time $12 \mathrm{~h}$ later. PEC cells were eluted at $36 \mathrm{~h}$ after inoculation and BrdU labeling was performed using a BrdU Labeling kit and analyzed by FCM. Data are representative of four independent experiments.

doi:10.1371/journal.pone.0060779.g004 
A

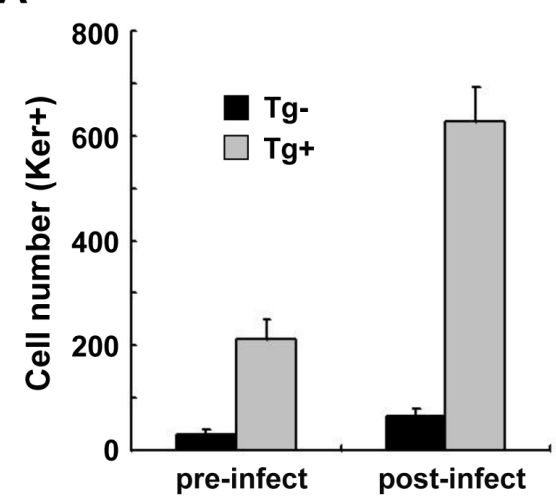

B

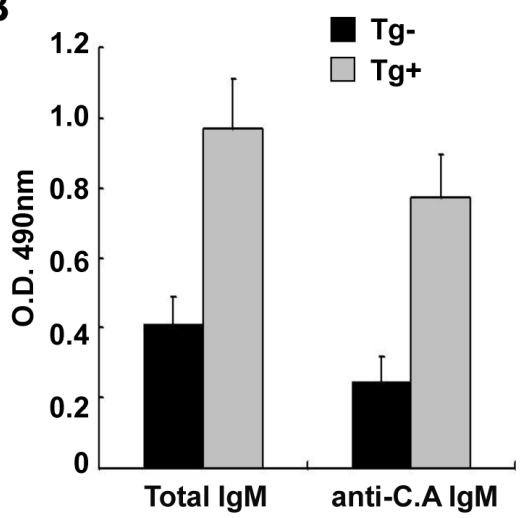

Figure 5. Analysis of $C$. albicans-specific B cells. (A) Cells collected from the PEC lavage before and after $C$. albicans inoculation were subjected to ELISPOT analysis using plate coated with mouse keratin. (B) Supernatant from the PEC B cells co-cultured with $C$. albicans were analyzed by ELISA to detect total IgM and C. albicans-specific IgM. Data shown are means \pm SD, $n=6$. ${ }^{*} P<0.01$. doi:10.1371/journal.pone.0060779.g005

macrophages, for a rapid and efficient pathogen clearance. $C$. albicans is the main commensal organism of the gastrointestinal tract, and it is reasonable to speculate that B-1 cells might have a role against $C$. albicans infection. In the past several years, it has been reported that B-1 cells play an important role in host defense against many pathogens including bacteria [4,23], viruses [6] and lymphatic filarial parasites [28]. However, the role of B-1 cells in fungi infection remains unclear. Using a monoclonal antibody $3 \mathrm{~B} 4$ and $\mathrm{TgV}_{\mathrm{H}} 3 \mathrm{~B} 4$ mice with $\mathrm{V}_{\mathrm{H}}$ derived from $3 \mathrm{~B} 4$, we have previously demonstrated a key role of natural antibodies in immune responses against C. albicans infection [8]. In this study, we explored the role and responses of B-1 cells to C. albicans infection by using i. p. fungi inoculation. We found that $\mathrm{TgV}_{\mathrm{H}} 3 \mathrm{~B} 4$ mice cleared the peritoneal $C$. albicans infection more efficiently, and level of $C$. albicans-reactive $\mathrm{IgM}$ in the $\mathrm{PEC}$ of $\mathrm{TgV}_{\mathrm{H}} 3 \mathrm{~B} 4$ mice was higher than that of control. Number of B-la cells was also increased, which was mainly due to enhanced B-1 cell proliferation. Furthermore, C. albicans-specific B cells increased numerously in $\mathrm{TgV}_{\mathrm{H}} 3 \mathrm{~B} 4$ mice after $C$. albicans infection. These data suggested that upon peritoneal C. albicans infection, C. albicansspecific B-1 cells proliferate actively and produce a large amount of natural IgM to clear the pathogen. It also indicated that B-1 cells play a critical role in host defense against fungal infection.

One of the most important functions of B-1 cells is producing natural antibodies; however, where B-1 cells produce natural antibodies is not fully understood. Studies showed that PEC B cells are precursors of splenic IgM natural antibody-producing cells and IgA producing plasma cells in murine gut [29,30]. Recently, Fagarasan et al found that antibody production by B-1 cells is closely related with their migration capacity to other lymphoid organs [31]; Wen et al showed that B-1 cells migrate to spleen and produce antibodies [32]. In our study, however, there was anti- $C$. albicans natural antibodies exist in the PEC of $\mathrm{TgV}_{\mathrm{H}} 3 \mathrm{~B} 4$ and littermate, and $\mathrm{TgV}_{\mathrm{H}} 3 \mathrm{~B} 4$ mice had much higher level of $C$. albicans-specific natural antibodies, indicating that B-1 cells can also produce natural antibodies in PEC without the need for migration.

After C. albicans inoculation in PEC, there was a rapid increase of C. albicans-specific IgM and C. albicans-specific B cells, indicating that the pre-existing C. albicans-reactive B-1 cells in PEC acted actively in early defense against infection. Clonal expansion of B-1 cells after infection has been discussed in several literatures; however, the data from different studies are inconsistent with one other. Baumgarth et al found that the protection against influenza virus infection by $\mathrm{B}-1$ cells-derived IgM antibodies does not entail significant increases in their normal serum levels after infection [33], suggesting that clonal expansion and increased IgM secretion is not initiated in vivo after infection. In Matin's paper, however, T15 idiotype expressing B-1 cells expanded vigorously in both PEC and spleen [25]. Our results are in consistent with Martin's study: C. albicans-specific B-1 cells proliferate in the PEC, and produce a high amount of natural antibody to clear $C$. albicans infection. The absence of B-1 cell expansion in Baumgarth's work may be due to a different route of infection: blood steam transmitted virus may not have the chance to meet B-1 cells in the spleen and PEC. While in our and Matin's experiment, i. p. infection were applied, and B-1 cells could contact with the pathogen and were stimulated to proliferate and produce antibody. Besides natural antibodies and B-1 cells, there are many other components of innate immunity against $C$. albicans infection in PEC, including epithelial cells, macrophages, neutrophils, NK cells, complement, and so on. Mechanisms of cooperation between different cells remain to be further investigated in the future.

As the transgene used to construct the $\mathrm{TgV}_{\mathrm{H}} 3 \mathrm{~B} 4$ mice contains only the IgH $\mu$ chain; consequently, the effect of other isotypes of immunoglobulin such as IgG cannot be explored using our system. The infection in our model was limited in the PEC, and the role of B-1 cells in disseminated C. albicans infection cannot be explored. More studies are needed to further our understanding on the role of B-1 cells in host defense against fungi infection.

\section{Materials and Methods}

\section{Ethics Statements}

The animal husbandry, experiments and welfare were conducted in accordance with the Detailed Rules for the Administration of Animal Experiments for Medical Research Purposes issued by the Ministry of Health of China, and were approved by the Animal Experiment Administration Committee of Fourth Military Medical University. Mice were raised in the specific pathogen free conditions on the C57BL/6 background, and were manipulated with every specific care to reduce the suffering of the mice during the experiments. 
Mice

Transgenic mice with $\mathrm{V}_{\mathrm{H}}$ derived from a monoclonal antibody 3B4 were generated by our group as described previously [8]. The mice were housed in special pathogen free conditions, and backcrossed with C57BL/6 mice for more than eight generations before analysis. All animal protocols were approved by the University's Animal Research Committee.

\section{Fungal inoculation and PEC lavage preparation}

C. albicans (ATCG 90028) were cultured in the Sabouraud's dextrose medium. For in vivo inoculation, $2 \times 10^{6}$ C. albicans yeasts were injected i. p. into $6 \sim 8$-week-old $\mathrm{TgV}_{\mathrm{H}} 3 \mathrm{~B} 4$ mice and littermate control. At different time point after inoculation $(6 \mathrm{~h}$, $12 \mathrm{~h}, 24 \mathrm{~h}, 36 \mathrm{~h}$ ) the mice were sacrificed. PEC lavage was eluted as described previously. In brief, a small hole was cut by scissors on the abdomen wall of the mice, and $1 \mathrm{ml}$ PBS was injected into the PEC with a pipette. Then a pasture tube was used to collect the cell suspension from the PEC. The same procedure was repeated three times and about $3.5 \mathrm{ml}$ lavage from the PEC can be harvested. The supernatant of the first $1 \mathrm{ml}$ of elution was saved for cytokine analysis, and the cells from all the three elution were pooled and subjected to flow cytometry (FCM) analysis and colony-forming assay immediately. Three mice were included in one group and each experiment was repeated for at least three times.

\section{Colony-forming assay and cytokine detection}

Living yeasts were revealed by a colony-forming assay. In brief, the elution were spread onto an agar plate and cultured at $37^{\circ} \mathrm{C}$ overnight, and then the colonies were counted. Cytokines in the elution were analyzed by using a Cytometry Beads Array kit (BD Bioscience, San Diego, CA) according to the manufactures instruction.

\section{ELISA}

To measure C. albicans-reactive IgM, C. albicans yeasts were seeded in microtitre plates (Nunc, Roskilde, Denmark) at a density of $1 \times 10^{5} / 100 \mu \mathrm{l}$ in RPMI 1640 and cultured at $37^{\circ} \mathrm{C}$ for $2 \mathrm{~h}$ to let yeast cells adhere tightly onto the plates, as described previously [8]. For analysis of mouse IgM, goat anti-mouse $\mu$ chain antibody (Sigma-Aldrich) was coated to microtitre plates at a concentration of $1 \mu \mathrm{g} / \mathrm{ml}$. PEC lavage from C. albicans inoculated $\mathrm{TgV}_{\mathrm{H}} 3 \mathrm{~B} 4$ and control mice or supernatant of cell culture were added and incubated at room temperature for $1 \mathrm{~h}$. After washing, the biotinlabeled anti-IgM (Sigma-Aldrich) was added and incubated, followed by incubation with the streptavidin-horseradish peroxidase, and developed by O-phenylenediamine.

\section{Flow cytometry}

Cells collected from mouse PEC lavage were stained with antibodies for $30 \mathrm{~min}$ on ice, and analyzed by using a FACSCalibur $^{\text {TM }}$ (BD Immunocytometry Systems, San Jose, CA). Dead cells were excluded by propidium iodide staining. Data were analyzed by using the Cellquest ${ }^{\text {TM }}$ software. Antibodies

\section{References}

1. Boes M (2000) Role of natural and immune IgM antibodies in immune responses. Mol Immunol 37: 1141-1149.

2. Quintana FJ, Cohen IR (2004) The natural autoantibody repertoire and autoimmune disease. Biomed Pharmacother 58: 276-281.

3. Belperron AA, Bockenstedt LK (2001) Natural antibody affects survival of the spirochete Borrelia burgdorferi within feeding ticks. Infect Immun 69: 64566462 . used in analyses included: anti-CD14 (rmC5-3), anti-Gr-1 (RB68C5), anti-CD5 (53-7.3), anti-CD19 (1D3), anti-Mac-1 (M1/70). All the antibodies were purchased from BD PharMingen (San Diego, CA).

\section{BrdU incorporation}

0.6mg (200 $\mu \mathrm{L} /$ mouse) BrdU (5-Bromo-2-deoxyuridine) (Sigma-Aldrich) was i. p. injected with fungal inoculation to $\mathrm{TgV}_{\mathrm{H}} 3 \mathrm{~B} 4$ mice and littermate control, and was injected for the second time $12 \mathrm{~h}$ later. After $36 \mathrm{~h}$ of inoculation, cells from PEC of mice were subjected for BrdU staining, which was performed using a BrdU Labeling kit (BD PharMingen, San Diego, CA) according to the manufacturer's instructions. Cells were then analyzed by FGM.

\section{Enzyme-linked immunoSPOT (ELISPOT) assay}

PEC B cells were sorted by first staining with anti-mouse CD19biotin (BD Biosciences) and then by BD IMag magnetic beads conjugated with avidin (BD Biosciences) according to the manufacturer's instructions. Purified B cells were plated at $2 \times 10^{5}$ cells/well in 96-well plates pre-coated with $20 \mu \mathrm{g} / \mathrm{ml}$ of purified mouse epidermis keratin, as the 3B4 antibody can also bind keratin. Cells were stimulated with LPS $(50 \mu \mathrm{g} / \mathrm{ml}$, SigmaAldrich) for 5 days at $37^{\circ} \mathrm{C}$ in an atmosphere of $5 \% \mathrm{CO}_{2}$. Wells were washed thoroughly with PBS containing $0.02 \%$ Tween-20, and the biotin-labeled anti-IgM was added. Plates were incubated for $2 \mathrm{~h}$ at room temperature, washed, and incubated with the streptavidin-alkaline phosphotase (Jackson Immunoresearch, Boston, MA) for $75 \mathrm{~min}$ at room temperature. Spots were developed by addition of the BCIP substrate (Sigma-Aldrich), and the reaction was stopped by washing extensively with water. Wells were counted under a microscope.

\section{In vitro cell culture}

PEC B cells were sorted as described above. The sorted cells were plated at a density of $1 \times 10^{5}$ cells/well in 96-well plates. $\gamma$ irradiated C. albicans yeasts were seeded in the well at $5 \times 10^{5}$ cells/ well and co-cultured with PEC B cells. After 3 days, the supernatant of culture was collected and subjected to ELSA analysis of total IgM and C. albicans-specific IgM.

\section{Statistics}

ANOVA was used to determine the statistical significance of values among experimental groups. Statistical significance was defined as $\mathrm{p}<0.05$.

\section{Acknowledgments}

We thank Hua Han for his suggestion and Demirjian Marine for her critical reading and improvement of writing.

\section{Author Contributions}

Conceived and designed the experiments: WL YL. Performed the experiments: RT MF JR ZZ JA. Analyzed the data: WL YL. Wrote the paper: WL YL.

4. Boes M, Prodeus AP, Schmidt T, Carroll MC, Chen J (1998) A ritical role of natural immunoglobulin $\mathrm{M}$ in immediate defense against systemic bacterial infection. J Exp Med 188: 2381-2386.

5. Lepper PM, Moricke A, Held TK, Schneider EM, Trautmann M (2003) Kantigen-specific, but not $\mathrm{O}$-antigen-specific natural human serum antibodies promote phagocytosis of Klebsiella pneumoniae. FEMS Immunol Med Microbiol 35: 93-98. 
6. Ochsenbein AF, Fehr T, Lutz C, Suter M, Brombacher F, et al. (1999) Control of early viral and bacterial distribution and disease by natual antibodies. Science 286: 2156-2159.

7. Shibuya A, Sakamoto N, Shimizu Y, Shibuya K, Osawa M, et al. (2000) Fc $\alpha / \mu$ receptor mediates endocytosis of IgM-coated microbes. Nat Immunol 1: 441446.

8. Li W, Fu M, An JG, Xing Y, Zhang P, et al. (2007) Host defence against C. albicans infections in IgH transgenic mice with $\mathrm{V}(\mathrm{H})$ derived from a natural antikeratin antibody. Cell Microbiol 9: 306-315.

9. Taborda CP, Casadevall A (2002) CR3 (CD11b/CD18) and CR4 (CD11c/ CD18) are involved in complement-independent antibody-mediated phagocytosis of cryptococcus neoformans. Immunity 16: 791-802.

10. Zhang MX, Bohlman MC, Itatani G, Burton DR, Parren PW, et al. (2006) Human recombinant antimannan immunoglobulin G1 antibody confers resistance to hematogenously disseminated candidiasis in mice. Infect Immun74: 362-369.

11. Maiti PK, Kumar A, Kumar R, Mohapatra LN (1985) Role of antibodies and effect of BCG vaccination in experimental candidiasis in mice. Mycopathologia; 91: 79-85.

12. Wagner RD, Vazquez-Torres A, Jones-Carson J, Warner T, Balish E (1996) B cell knockout mice are resistant to mucosal and systemic candidiasis of endogenous origin but susceptible to experimental systemic candidiasis. J Infect Dis 174: 589-597.

13. Kozel TR, MacGill RS, Percival A, Zhou Q (2004) Biological activities of naturally occurring antibodies reactive with Candida albicans mannan. Infect Immun 72: 209-218.

14. Zhang MX, Lupan DM, Kozel TR (1997) Mannan-specific immunoglobulin G antibodies in normal human serum mediate classical pathway initiation of C3 binding to Candida albicans. Infect Immun 65: 3822-3827.

15. Fu M, Fan PS, Li W, Li CX, Xing Y, et al. (2007) Identification of poly-reactive natural IgM antibody that recognizes late apoptotic cells and promotes phagocytosis of the cells. Apoptosis 12: 355-362.

16. Berland R, Wortis HH (2002) Origins and functions of B-1 cells with notes on the role of CD5. Annu Rev Immunol 20: 253-300.

17. Hardy RR, Hayakawa K (2001) B cell development pathways. Annu Rev Immuno 19: 595-621.

18. Hayakawa K, Asano M, Shinton SA, Gui M, Allman D, et al. (1999) Positive selection of natural autoreactive B cells. Science 285: 113-116.

19. Hayakawa K, Asano M, Shinton SA, Gui M, Wen LJ, et al. (2003) Positive selection of anti-thy-1 autoreactive B-1 cells and natural serum autoantibody production independent from bone marrow B cell development. J Exp Med 197: 87-99.
20. Binder CJ, Shaw PX, Chang MK, Boullier A, Hartvigsen K, et al. (2005) The role of natural antibodies in atherogenesis. J Lipid Res 46: 1353-1363.

21. Rowley B, Tang L, Shinton S, Hayakawa K, Hardy RR (2007) Autoreactive B-1 cells: constraints on natural autoantibody $\mathrm{B}$ cell antigen receptors. J Autoimmun 29: $236-245$.

22. Zhang M Jr, Austen WG, Chiu I, Alicot EM, Hung R, et al. (2004) Identification of a specific self-reactive IgM antibody that initiates intestinal ischemia/ reperfusion injury. Proc Natl Acad Sci USA 101: 3886-3891.

23. Haas KM, Poe JC, Steeber DA, Tedder TF (2005) B-1a and B-1b cells exhibit distinct developmental requirements and have unique functional roles in innate and adaptive immunity to S. pneumoniae. Immunity 23: 7-18.

24. Martin F, Kearney JF (2000) Positive selection from newly formed to marginal zone B cells depends on the rate of clonal production, CD19, and btk. Immunity; 12: 39-49.

25. Martin F, Oliver AM, Kearney JF (2001) Marginal zone and B-1 B B cells unite in the early response against T-independent blood-borne particulate antigens. Immunity 14: 617-629.

26. Xing Y, Li W, Lin Y, Fu M, Li CX, et al. (2009) The influence of BCR density on the differentiation of natural poly-reactive $\mathrm{B}$ cells begins at an early stage of $\mathrm{B}$ cell development. Mol Immunol 46: 1120-1128.

27. Janeway CA (2001) Immunobiology. 5th edition. New York: Garland Pub.

28. Paciorkowski N, Porte P, Shultz LD, Rajan TV (2000) B-1 B lymphocytes play a critical role in host protection against lymphatic filarial parasites. J Exp Med 191: 731-736.

29. Kawahara T, Ohdan H, Zhao G, Yang YG, Sykes M (2003) Peritoneal cavity B cells are precursors of splenic IgM natural antibody-producing cells. J Immunol 171: 5406-5414.

30. Kroese FG, Butcher EC, Stall AM, Lalor PA, Adams S, et al. (1989) Many of the IgA producing plasma cells in murine gut are derived from self-replenishing precursors in the peritoneal cavity. Int Immunol 1: 75-84.

31. Fagarasan S, Shinkura R, Kamata T, Nogaki F, Ikuta K, et al. (2000) Alymphoplasia (aly)-type nuclear factor kappaB-inducing kinase (NIK) causes defects in secondary lymphoid tissue chemokine receptor signaling and homing of peritoneal cells to the gut-associated lymphatic tissue system. J Exp Med 191: $1477-1486$.

32. Wen L, Shinton SA, Hardy RR, Hayakawa K (2005) Association of B-1 cells with follicular dendritic cells in spleen. J Immunol 174: 6918-6926.

33. Baumgarth N, Herman OC, Jager GC, Brown LE, Herzenberg LA, et al. (2000) $\mathrm{B}-1$ and B-2 cell-derived immunoglobulin $\mathrm{M}$ antibodies are nonredundant components of the protective response to influenza virus infection. J Exp Med 192: $271-280$ 